\title{
Se opp for røvertidsskrifter
}

\author{
Useriøse tidsskrifter som fremstår som vitenskapelige, men som forsøker å lure deg for penger, \\ bør på norsk kalles røvertidsskrifter.
}

Åpne elektroniske fagtidsskrifter gir leserne gratis tilgang til fagfellevurderte artikler. Slik åpen publisering (open access) er i de senere år blitt vanlig. Dermed får alle fri tilgang til vitenskapelige artikler. Kostnadene ved publisering dekkes gjerne av en avgift, betalt av forfatterne. Dessverre har enkelte sett på dette som en måte å skaffe seg lettjente inntekter på. Å legge ut artikler på nett uten redaksjonell eller faglig bearbeiding er en kjapp og enkel måte å tjene penger.

I oktober 2013 ble det i Science publisert en artikkel som satte søkelyset på denne virksomheten (1). Journalisten John Bohannon sendte inn et konstruert manus til 304 open access-tidsskrifter. Manuskriptet hadde så mange feil og mangler at det åpenbart skulle ha blitt refusert. Imidlertid ble det akseptert for publisering av over halvparten av tidsskriftene.

\section{Røver eller rovdyr?}

Begrepet predatory journals ble første gang brukt av den amerikanske forskningsbibliotekaren Jeffrey Beall. I 2010 presenterte han den første listen over slike tidsskrifter på bloggen sin, Scholarly Open Access (2). Der publiserer han oversikter over «potential, possible, or probable predatory scholarly open-access publishers» (2). I 2012 tok det for alvor av - antallet nye useriøse tidsskrifter nærmest eksploderte (3). Begrepet «predatory» trenger ikke å være begrenset til tidsskrifter, det kan like gjerne brukes om utgivere (4).

Den norske oversettelsen røvertidsskrifter ble lansert i Tidsskriftet i februar 2013 i omtalen av en artikkel om dette fenomenet (5). Tidsskriftets redaktør Charlotte Haug tok et oppgjør med de useriøse aktørene innen akademisk publisering og påpekte at man slår mynt på forfatteres ønske om rask publisering av forskningsresultater. «Flere av de nye utgiverne seiler under flagget «åpen publisering», $\mathrm{og}$ blir internasjonalt nå omtalt som røvertidsskrifter (predatory journals). Målsettingene deres er kommersielle fremfor vitenskapelige» (6).

I engelskordboken er adjektivet predatory omtalt med fire betydninger: plyndrings-, plyndrende, plyndre-; røver-; rov-, rovdyr-; rovgrisk, rovlysten (7). På svensk har man i denne sammenheng forsøkt med rovdjursförlag (8), men det synes ikke å ha slått an. Etter min mening er røvertidsskrifter mer konkret og dermed mer passende.

Fenomenet røvertidsskrifter er relevant for leger og forskere. Det er lett å bli lurt når man gjerne vil ha sine forskningsartikler publisert raskt og bekymringsfritt. Da er det verdt å bli minnet om at nærmere 200 slike tidsskrifter for et par år siden ble nullet av Universitets- og høyskolerådet, fordi de ble oppfattet som useriøse (9).

Det er bare toppen av isfjellet. Vokt deg for røvertidsskriftene.

\section{Erlend Hem}

erlend.hem@medisin.uio.no

Erlend Hem (f. 1970) er dr.med. og assisterende sjefredaktør i Tidsskriftet

Litteratur

. Bohannon J. Who's afraid of peer review? Science 2013; 342: 60-5.

2. Beall J. Scholarly Open Access. http://scholarlyoa.com (9.4.2014)

3. Butler D. Investigating journals: The dark side of publishing. Nature 2013; 495: 433-5.

4. Beall J. Predatory publishers are corrupting open access. Nature 2012; 489: 179.

5. Bjerkestrand S. - Åpen publisering har en bakside. Tidsskr Nor Legeforen 28.2.2013. http://tidsskriftet.no/Innhold/Nyheter/2013/

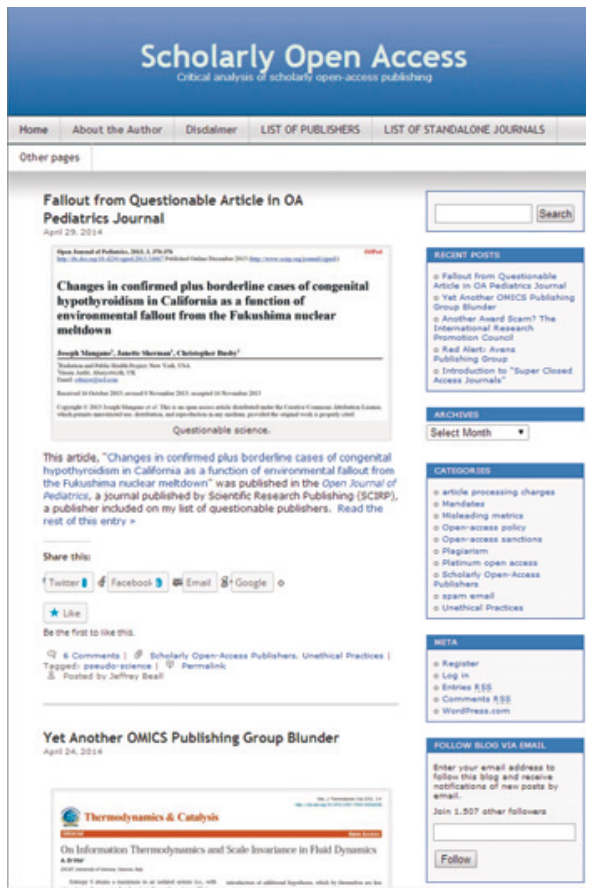

Useriøse utgivere står for 5-10 \% av alle artikler som publiseres som åpen publisering (open access), hevder Jeffrey Beall (3). Faksimile fra bloggen hans, Scholarly Open Access (2)

Februar/AApen-publisering-har-en-bakside (9.4.2014).

6. Haug C. The downside of open-access publishing N Engl J Med 2013; 368: 791-3.

7. Stor engelsk ordbok. I: http://ordnett.no/ search?search=predatory\&lang=en (9.4.2014)

8. Olsson H. «Predatory publishers»-rovdjursförlag. Läkartidningen 2012; 109: 2136. http://ww2.lakartidningen.se/07engine.php? articleld $=18908$ (9.4.2014)

9. Monsen TH. 188 tidsskrifter «nullet». Universitetsavisa 8.5.2012. www.universitetsavisa.no/ forskning/article13587.ece (9.4.2014).

Mottatt 9.4. 2014 og godkjent 27.4. 2014. Redaktør: Marit Fjellhaug Nylund. 